\title{
Key marketing tools formation and application in business management
}

\section{Kateryna Orlova}

\author{
Zhytomyr State Technological University \\ 103 Chudnivska str., 10005 Zhytomyr, Ukraine \\ PhD, Associate Professor, Department of Economics and Entrepreneurship
}

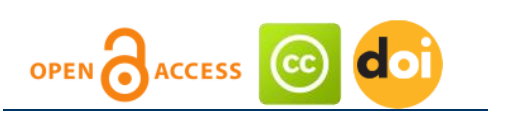

Article history:

Received: September 20, 2018

1st Revision: October 10, 2018

Accepted: October 29, 2018

\section{JEL classification:}

M21

M31

L21

DOI:

10.14254/jems.2018.3-2.6

\begin{abstract}
The key marketing tools in business management have been identified. It has been proven that marketing plays an extremely important role in providing the effectiveness of enterprises' functioning. Marketing has been considered as an activity which is aimed at identification and satisfaction of consumers' needs. It has been stated that the rational use and combination of marketing tools form an important prerequisite for the sustainable and effective functioning of business subject. The key marketing tools have been defined and grouped according to their spheres of use. Three main groups of marketing tools have been proposed: market and environment of functioning analysis tools; tools for formation of activity strategy; formation of a communication policy tools. The brief description of the main marketing tools has been provided. The importance of the rational and efficient use and combination of marketing tools has been proven.
\end{abstract}

Keywords: business management, marketing, marketing tools, consumers, sales, sustainability, marketing-mix, groups of marketing tools

\section{Introduction}

Providing the stability of functioning and development of business plays an extremely important role under conditions of globalization and competition aggravation in terms of ensuring the rationality, efficiency and effectiveness of managerial decisions. It should be mentioned, that the special emphasis shifts to the issues of products sales organization, as even the most effective production will not provide the economic activity profitability in the absence of effective sales system. At the same time, diversification of consumers' inquiries with the simultaneous decrease of solvent demand, increase of competitors number and quality of competitive relations actualize the activation of sales activity of business. Insufficient level of sales activity organization leads to the accumulation of unsold products at warehouses of economic entities, as a result - to distraction of funds from the turnover, to corresponding slowdown of the invested capital turnover and negative

Corresponding author: Kateryna Orlova

E-mail: orlova_ekaterina@ukr.net

This open access article is distributed under a Creative Commons Attribution (CC-BY) 4.0 license. 
impact on the enterprise's financial condition. The client-oriented approach comes in first place and the tool of its implementation is marketing. Marketing as the type of managerial activity is aimed at the maximum possible research of market with the objective of identification and satisfaction of consumers' needs, gaining and maintenance of the target market share. Therefore, the use of marketing tools in business management stands as important, if not crucial, element of effective management system of any business subject.

\section{Materials and methods}

Informational basis for the research was formed by publications of leading Ukrainian and foreign scientists. The relevance of the defined issues related to the organization of efficient sales system of products with the marketing tools use caused a considerable scientific interest to this sphere.

In particular, J. Burnett (2008) and P. Kotler and K. L. Keller (2012) should be mentioned specifically, as they implement a comprehensive approach to research in the sphere of marketing, reflecting a significant number of both theoretical and applied aspects of the enterprise's marketing activity organization in their researches. N. T. Bendle and X. (S.) Wang (2017) emphasize the importance of marketing in terms of creating an additional value of the enterprise and determine the need for information provision in the field of marketing decisions through marketing accounts implementation in the system of internal reporting. In the authors' opinion, part of the marketing costs can be referred as to investments that form the relevant market-based assets of the enterprise. Under that context an appropriate and rational use of the marketing tools is necessary for the enterprise's effective performance.

The researches of A. Afonina (2015), F. Bachmann and J. Vaculík (2008) and C. L. Goi (2005) are devoted to the definition and study of the marketing tools use peculiarities. In particular, A. Afonina (2015) draws main attention to the strategic management tools and techniques, the component of which are marketing tools, and substantiates the interrelation between the financial indicators of enterprises' activity and the number and frequency of the management tools use. F. Bachmann and J. Vaculík (2008) and C. L. Goi (2005) investigate the structure of marketing-mix and determine features of its evolution under the current conditions. The need to apply a clientoriented approach is emphasized. V. Rossokha (2012) examines the differences in marketing tools use within the B2B (business-to-business) and B2C (business-to-client) sectors.

It should be noted that marketing tools evolve under the influence of external and internal factors, that determines the importance and expediency of further research in a mentioned sphere. P. Cegliński (2016) notes that marketing tools are constantly changing, including changes under the influence of information technologies development. In view of the above, the important place in the system of scientific research is the study of evolution and the peculiarities of marketing tools use in the context of the information and digital technologies development. Thus, 0. Maslak and S. Romanenko (2010) define the specifics of marketing tools use in the field of e-commerce. The research of F. Milichovský (2013) is devoted to the study of new marketing communication tools, in particular, those, used in social media.

It is clear that in the system of marketing management one of the key roles belongs to the consumer, who has a significant impact on the market conditions formation. D. Kjeldgaard, S. Askegaard, J. Ø. Rasmussen and P. Østergaard (2017) note the important role of consumers in shaping the dynamics of the market and transformation of market conditions. In this context, the rational use of marketing tools, aimed at formation of consumers' recognition of the enterprise and their commitment to its products, is extremely important. Taking into account the above and under the conditions of the development of information technologies and enhancing the role of social media marketing, L. de Vries, S. Gensler and P. S. H. Leeflang (2017) explore the relationship, role and features of the complex use of traditional advertising, firm-to-consumer messages and consumer-to-consumer messages in social media. Thus, we should note that the problem of the formation and use of marketing tools is quite widely covered in scientific literature.

At the same time, it should be mentioned, that the complexity of marketing as of a managerial activity, the growth of market environment uncertainty and dynamism of the influence factors determine the expediency of further scientific researches in the sphere of generalization and systematization of marketing tools according to the main spheres of marketing activity of business subjects.

The conducted research provided for use of the following methods: methods of statistical and economic analysis - to determine the trends of changes in sales volumes and producers' prices indexes; dialectic, logical, generalization, scientific abstraction, system approach - to identify the key marketing tools; grouping - to evolve the groups of marketing tools; graphical and tabular - to provide the visual presentation of the research results. 


\section{Objective of research}

The objective of the research is to provide generalization and further development of theoretical basis of marketing tools formation in business management.

\section{Results}

Under conditions of competition intensification, which is due to both the competitors number growth and decrease of solvent demand, the issues of sales organization play an important role in shaping the principles of business subjects stable functioning and development. Due to efficient sales organization, the enterprise is able to provide the incoming cash flows, which are directed at reimbursement of expenses and reproduction of economic activity, to maintain an appropriate level of solvency and financial stability of the enterprise, to ensure its functioning profitability. The growth of sales volumes combined with a balanced and rational cost-formation policy is one of the key reserves of business effectiveness increase. The mentioned causes the importance of rational organization of sales as of a business management component.

The relevance of the defined task for Ukrainian industrial enterprises is confirmed by the data of the State Statistics Service of Ukraine (Table 1). The data in Table 1 is given without taking into account the temporarily occupied territory of the Autonomous Republic of Crimea, the city of Sevastopol, for 2014-2017 - also without part of the temporarily occupied territories in the Donetsk and Luhansk regions.

Table 1: The indicators of industrial enterprises activity in 2010-2017

\begin{tabular}{lcccccccc}
\hline Indicators & $\mathbf{2 0 1 0}$ & $\mathbf{2 0 1 1}$ & $\mathbf{2 0 1 2}$ & $\mathbf{2 0 1 3}$ & $\mathbf{2 0 1 4}$ & $\mathbf{2 0 1 5}$ & $\mathbf{2 0 1 6}$ & $\mathbf{2 0 1 7}$ \\
\hline $\begin{array}{l}\text { Sales volumes of industrial } \\
\text { products, bn UAH }\end{array}$ & 1043.1 & 1305.3 & 1367.9 & 1322.4 & 1428.8 & 1776.6 & 2158.0 & $2608.0^{*}$ \\
$\begin{array}{l}\text { Index of sales volumes of } \\
\text { industrial products, \% to } \\
\text { previous year }\end{array}$ & 129.3 & 125.1 & 104.8 & 96.7 & 108.0 & 124.3 & 121.5 & $120.9^{*}$ \\
$\begin{array}{l}\text { Producers' prices index, \% } \\
\text { December to previous year } \\
\text { December }\end{array}$ & 118.7 & 114.2 & 100.3 & 101.7 & 131.8 & 125.4 & 135.7 & 116.5 \\
\hline
\end{tabular}

* - preliminary data data (n.d.)

Source: formed and calculated by the author on the basis of State Statistics Service of Ukraine

According to the data in Table 1, we note that during the researched period (except for 2013) positive growth rates of sales volume were observed. At the same time, during the years 20132016, the producers' prices index exceeded the sales volume index, which confirms that the growth of sales volumes was due to the price factor increase (inflation). The situation in 2017 improved somewhat, as the sales volumes index was $120,9 \%$ versus $116,5 \%$ of the producers' prices index, thus, growth was achieved both due to the price and quantity factors. At the same time, in general, defined trends point to significant problems in the sphere of industrial enterprises' sales organization. That indicates the relevance and expediency of finding efficient mechanisms for promoting products, in particular marketing tools.

Marketing in its essence is a specific type of managerial activity, aimed at achieving strategic and tactical goals of establishing effective communications with stakeholders (first of all, consumers) and effective positioning of the enterprise. We believe that the formation of the communications system within the marketing activity should consider the key categories of all stakeholders: suppliers, competitors, state institutions, etc. However, the primary object of marketing influence is the consumer and the motives of his behavior in the market, so further research will be conducted taking into account the mentioned above.

Another reason of putting the special emphasis on the context of marketing tools use for the formation of communication with consumers' is their role in market conditions transformation. Giesler (2008) states that the struggle between opposing groups of customers and / or between customers and producers is one of the most influential factors of market conditions formation (as cited in Kjeldgaard, Askegaard, Rasmussen \& Østergaard, 2017, p. 52).

Main tasks of marketing include identification, formation and satisfaction of consumers' needs in order to achieve the goals of business subject. Thus, marketing in its essence is a dialectical combination of science and art. On the one hand, the definition of the consumers' motives, the study of trends in the market situation, the analysis of the market conditions are carried out through a 
combination of scientific methods, on the other - the identification of consumers' hidden motives and the effective management of them have a creative and artistic nature.

The formation of marketing as of a science dates back to the beginning of the twentieth century. At the same time, the systematic approach to the organization of marketing activity is associated with the name of Philip Kotler, who laid the foundations of modern marketing.

The necessity of sales organization under conditions of competition intensification and individualization of consumers' needs causes a large number of scientific researches in the sphere of marketing activity, but the expediency of further research is unconditional in the light of the transformation of economic relations in general and in the field of marketing in particular. On the base of the study of P. Kotler and K. Keller (2012); Šonková \& Grabowska (2015), we can determine the following modern peculiarities of marketing activity conducting:

- development of the network information technology. The Internet as a whole and social networks in particular occupy a significant place in the modern life of society, therefore, taking into account this peculiarity and using the opportunities in the field defined are important elements in the formation of the enterprise's effective marketing policy;

- globalization - the growth of the number, deepening and strengthening of the relations between markets, national economies in general and individual business subjects in particular leads, on the one hand, to increase of the competition between producers, on the other - to the growth of dynamism and uncertainty of the environment in which business functions;

- deregulation and privatization - reduction of the state's participation in economic relations, both in terms of the regulator and in terms of the direct participant in the relations leads to the intensification of the competition;

- increase of competition, which greatly complicates marketing activity and increases its cost to income ratio;

- convergence of industry sectors is due to the high degree of diversification of activities of large enterprises (including convergence as a result of the digital technologies development);

- transformation of forms and methods of retail sale in order to ensure the correspondence of consumers' inquiries individualization, in particular, in the context of the digitalization of the economy;

- reduction of the intermediaries number and increase of direct sales through the online services system;

- awareness and market power of consumers due to widespread access to information. Also, as a result of producers number increase, consumers have wider opportunities to influence the behavior of producers on the market. In order to take into account this peculiarity, business representatives can engage consumers to design and formation of product features to provide increase of their interest in the product.

A similar view on the transformation of the marketing activity conditions can also be observed in the work of František Milichovský (2013, p. 37), who notes that the communication policy of the company is influenced by four main factors:

- the existence of new technologies;

- growth of marketers' experience in providing differentiation of products and services in the consumers' eyes with comparison to competitors;

- personalization of advertisements based on consumers' actions on the Internet;

- presence of significant differences between individual demographic groups of consumers.

Thus, new realities of marketing under modern conditions cause the expediency of further researches in the sphere of formation and application of marketing tools in business management.

The practical application of marketing tasks is provided on the base of marketing tools use. The "Business Dictionary" service provides the following definition of marketing tools: "The techniques and materials used by those who are involved in the promotion of goods and services. Most business that need to sell their goods or services to the public will make extensive use of various marketing tools, such as market research and advertising to help further their success" (Business Dictionary, n.d.). According to Anna Afonina (2015, p. 20), marketing tools are the component of management tools and techniques, which is aimed on identification and satisfaction of consumers' needs. We agree with the given scientific positions and consider marketing tools as a complex of methods, techniques and tools, which can be used for identification, setting and achievement of business subject goals in the sphere of marketing. Moreover, marketing tools can be presented by both general (e.g. SWOT-analysis, benchmarking, etc.) and specific (e.g. segmentation, branding, contacts audit, etc.) tools and techniques.

The importance of effective formation and application of marketing tools can hardly be overestimated. Effective use of marketing tools is also important in the context of enterprise's value formation. As the ultimate goal of management is the increase of the enterprise's market value, marketing plays an important role in this process. In particular, expenses related to marketing tools 
use can be referred as to investments, which form intangible market-based assets (e.g. brand). In its turn, those assets increase the market value of the enterprise (Bendle \& Wang, 2017). P. Cegliński mentions, that today marketing tools gain special importance in combination with increase of marketing functions role at the enterprise. Competition aggravation forces enterprises' management to search for new more efficient ways of understanding the consumers' needs, creation of unique products, more effective sales channels and methods of communication with consumers. All the mentioned above leads to a significant interest in new, effective marketing tools (Cegliński, 2016, p. 11-12).

There are a lot of marketing tools in modern theory and practice. Their particular set, in its turn, depends on the enterprise's strategy, market behavior and competitive advantages. Each of the tools has its own strengths and weaknesses, thus, manager should understand impact and side effects of each tool in order to provide their rational combination and targeted use for ensuring the enterprise functioning effectiveness (Cegliński, 2016, p. 12).

It should be mentioned, that most of the scientists define marketing tools through the prism of so-called marketing-mix (or "4 Ps"), which in its essence represents the set of tools used for marketing goals achievement. The most popular in theory and practice concept of marketing-mix was originally proposed by E. Jerome McCarthy and includes the following components: product, price, place and promotion (Goi, 2005). Therefore, main marketing tools are defined in terms of product, price, communication and promotion policies of the enterprise. At the same time, high level of external environment dynamism, transformation of economic relations and conditions of business functioning objectively led to the evolution of the " 4 Ps" concept and the emergence of new approaches to the components of marketing-mix. We believe, that the special attention should be paid to the following two approaches (Fig. 1).

According to Fig. 1, we can observe, that marketing gurus P. Kotler and K. Keller believe, that under modern conditions the "4 Ps" complex should include (Kotler \& Keller, 2012, p. 25):

- people - reflects internal marketing, that means the orientation of all employees on the most effective interaction with consumers, formation of an attractive image of the enterprise. This component characterizes the role of employees in the enterprise's effective functioning providing;

- processes - reflect the level of creativity, organization and structure of marketing management at the enterprise; consumer;

- programs - characterize all the business subject activity, which is aimed at individual

- performance is considered within the concept of holistic marketing, that is, it envisages taking into account both financial and non-financial consequences (e.g. ecological, ethical, social etc.).

Figure 1: Evolution of approaches to the marketing-mix concept
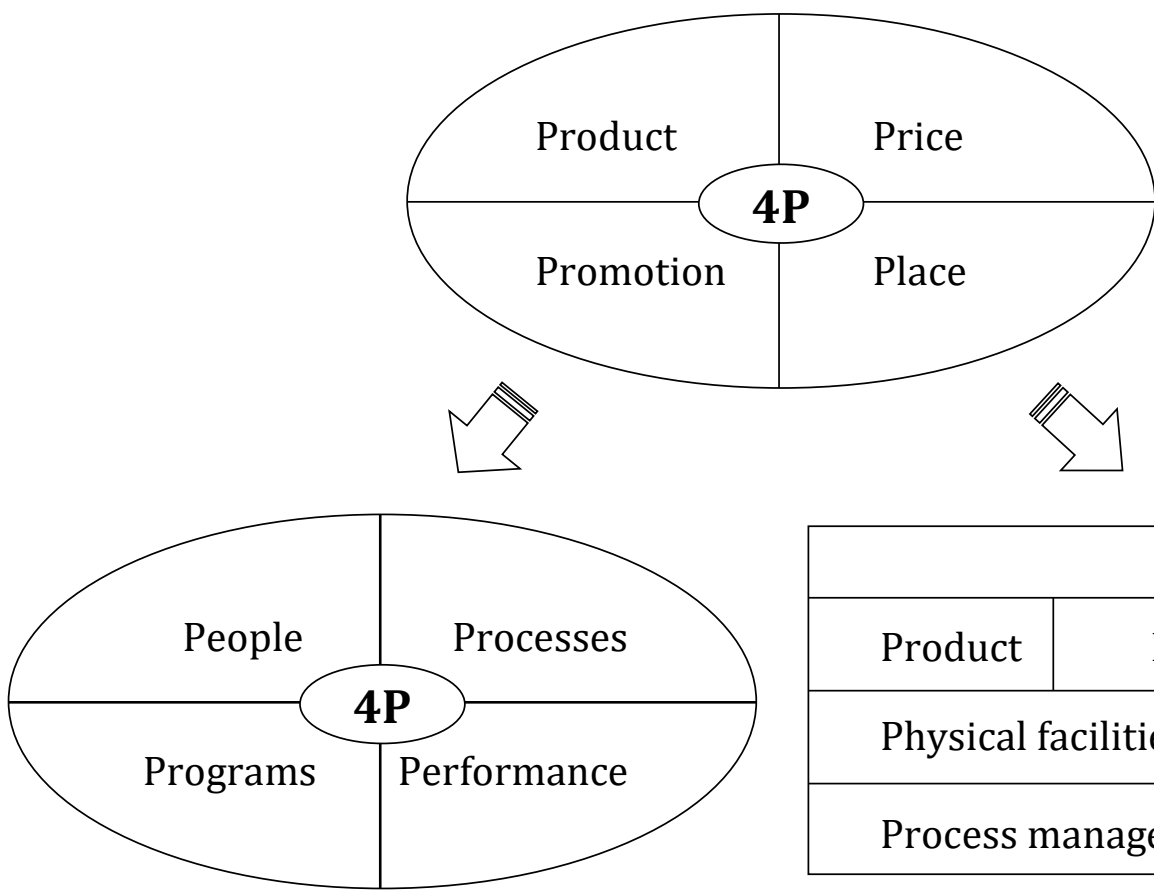

\begin{tabular}{|c|c|c|}
\hline \multicolumn{3}{|c|}{ 7P } \\
\hline Product & Price & Place \\
\hline Physical facilities & Promotion \\
\hline Process management & Personnel \\
\hline
\end{tabular}

Source: formed by the author on the base of (Goi, 2005; Kotler \& Keller, 2012, p. 25; Bachmann

\& Vaculík, 2008) 
Fabian Bachmann and Juraj Vaculík (2008) propose to extend the standard "4 Ps" complex with three components: physical facilities, process management and personnel. That means that to the mentioned by P. Kotler and K. Keller elements of process management and personnel the component of the physical facilities of the product or place where the services are provided is added.

So, the marketing-mix complex is a generalization of the main marketing tools that can be used in the business subject's activity. At the same time, it should be noted that modern theory and practice distinguish a much wider list of tools suitable for use in achieving marketing objectives. Thus, the analysis of the scientific works of J. Burnett (2008), D. Rigby and B. Bilodeau (2015), A. Afonina (2015), O. Maslak and S. Romanenko (2010), O. Lehkyi and O. Sokhatska (2016), V. Rossokha (2012), as well as generalization of the results of our own researches had provided the ability to form a list of the most common and widely-spread marketing tools, both general and specific. We consider it expedient to group these tools according to their intended use (Table 2).

On the basis of presented in Table 2 data, we can observe that the main spheres of marketing tools use are the following: market and environment of functioning analysis; formation of activity strategy; positioning / formation of a communication policy. We believe that the defining of such spheres of use is appropriate from the standpoint of the main business processes of enterprise's marketing activity: the identification of functioning conditions; development of strategic and tactical measures, based on certain conditions; formation of effective communication with the consumer. Consequently, we will provide a brief description of the identified groups of tools.

Market and functioning environment analysis tools include both general and specific components. So, general tools of the mentioned group include the following:

1. SWOT-analysis provides the identification of the strengths and weaknesses of the enterprise, opportunities and threats of the environment (Fuchedji, 2013). SWOT-analysis is an effective tool which provides the comparison of the enterprise's current state with the environment factors, including those in the field of marketing activity.

\section{Table 2: Key marketing tools in business management}

\begin{tabular}{ccc}
\hline $\begin{array}{c}\text { Market and functioning } \\
\text { environment analysis }\end{array}$ & Strategy formation & $\begin{array}{c}\text { Positioning / formation of } \\
\text { communication policy }\end{array}$ \\
\hline SWOT-analysis & GAP-analysis & Contacts audit \\
GAP-analysis & Boston Consulting Group & matrix \\
M. Porter's five forces model & McKinsey / GE matrix & Differentiation \\
Market analysis & Benchmarking & Branding \\
Consumers analysis & Key success factors concept & IT-marketing \\
Marketing research & Market segmentation & \\
Big data analysis &
\end{tabular}

Source: generalized and grouped by the author on the base of (Burnett, 2008; Rigby \& Bilodeau, 2015; Afonina, 2015; Maslak \& Romanenko, 2010; Lehkyi \& Sokhatska, 2016; Rossokha, 2012)

2. GAP-analysis provides the opportunity to identify so-called "gaps" in the market, that is, in essence, market niches, therefore, this tool can be attributed to both the analysis of the environment and the strategy formation groups. In our opinion, strategic "gaps" should be considered from three positions:

- demand "gaps" - the presence of dissatisfied demand due to the lack of relevant goods / services on the market;

- geographical "gaps" - the lack of a specific product / service in a particular geographic region or the difficulty of accessing it in connection with remoteness;

- price "gaps" - the presence of a specific product / service on the market, but at a price not corresponding to the request of a specific consumers group.

3. M. Porter's five forces model defines the main market forces with the following components: the existing level of competition, the threat of the emergence of new competitors, the market power of consumers, the market power of suppliers, the presence of commodity substitutes (Porter, 1998, p. 4).

4. The processes of informatization and globalization brought both advantages and disadvantages to enterprises. On the one hand, consumers have more information on products supply, that aggravates competition highly. On the other hand, enterprises also gained access to the consumers' information, which can be collected from different sources. So, if to speak about big data, its use is quite important in marketing activity of the enterprise. Big data can be used in 
different ways with the marketing purposes: modelling of the market forces tendencies, defining the consumers' needs and preferences, setting marketing goals, etc. But the vast range of information sources and big volume of the information received create objective difficulties for marketing managers to process the information. So, information technologies can help in that case. As D. Patel (2017) mentions, such tools can be used in order to manage big data in marketing: Improvado.io, Mixpanel, Skytree, Karmasphere, Jaspersoft, Marketing Evolution and others. Use of the mentioned and other information technologies for big data collection and processing forms a great help for marketing managers in managerial decisions substantiation.

We believe that the specific tools of the analysis group should include:

1. Market analysis involves the research of market conditions, market conjuncture, the state of the industry, consumers in the market, the main factors affecting the market situation.

2. Consumers analysis involves determining the main consumers' inquiries, the level of consumers' satisfaction, their complaints (Afonina, 2015, p. 23).

3. Marketing research is one of the key marketing tools. Marketing research provides collection and processing of irregular and specific information for solving specific marketing tasks. There are 5 main areas of marketing research: research of market, sales, products, advertising, corporate growth and development (Burnett, 2008).

The next group of tools provides an informational and analytical basis for business strategy formation. It should be noted that only the market segmentation can be attributed to purely specific tools in this group. So, the mentioned group includes the following tools:

1. The Boston Consulting Group matrix is used to identify priority strategies and development directions for strategic business units, using such development indicators as the relative market share and the rate of sales growth.

2. The McKinsey matrix represents a more complex variant of the BCG matrix and analyzes complex indicators of market attractiveness and competitiveness of the enterprise, each of them, in its turn, is calculated on the basis of individual development indicators. This tool is used to determine the expediency of further investing in a particular strategic product.

3. Benchmarking involves identifying a specific standard or model for comparison and orientation in future development on this model. Moreover, the standard can be based on the development indicators of a real enterprise in a specific industry, as well as on the imaginary model with ideal parameters (Quality Management, n.d.).

4. Key success factors concept involves the identification and efficient use of competitive advantages of an enterprise under conditions of a specific market and time.

5. Market segmentation is the basic tool for developing a marketing strategy of the enterprise and involves the division of consumers into groups according to certain criteria, such as demographic characteristics, consumer's income level, etc.

The last group is represented by tools aimed at establishing effective communication with consumers, as well as forming the appropriate image of the enterprise. The main tools of this group, in our opinion, should include:

1. Contacts audit involves the study of channels of communication with the consumer, in addition to advertising itself. That envisages analysis of all possible ways of informing the consumer about the product and the business as a whole (for example, correspondence, disclosure of reports, personal communication with the employees of the firm) in order to activate the most effective channels of communication.

2. It is advisable to consider positioning and differentiation in combination, since both instruments complement each other. Thus, positioning aims at creating the desired image of an enterprise to attract consumers, while differentiation involves ensuring the identification of a particular business and distinguishing it from among competitors (Maslak \& Romanenko, 2010, p. 184).

3. Branding is an element of positioning and differentiation, and involves the formation of a name, a designation, a design or a combination of them in order to provide clear identification the products of one firm from others (Kotler \& Keller, 2012, p. 241). Today branding is one of the key marketing tools that ensures the differentiation of business in the market and the formation of its long-term competitive advantages (Rossokha, 2012, p. 88).

4. IT-marketing is a generalizing name for a combination of new ways of forming a communication policy of business subject in the context of the economy digitalization. The rapid development of information technologies in general and social networks in particular led to the emergence of such new marketing tools as viral marketing, blogging, flash mobs, provocative marketing, etc. (Lehkyi \& Sokhatska, 2016, p. 85-86). Another important issue is the social media marketing (SMM), as today a lot of consumers, both current and potential, spend their time in social media, instead of watching TV or listening to radio. Thus, effective use of SMM tools is crucial to enterprises, especially to those, whose target segment are young people. It should be mentioned, 
that there are two main methods of enterprise's recognition and preference formation within consumers: firm-to-consumer messages and consumer-to-consumer messages. Both of them are important and show the best performance in combination with the traditional advertising (De Vries, Gensler, \& Leeflang, 2017, p. 2).

Thus, modern marketing involves the use of a wide range of tools in order to achieve the goals and objectives of a business subject.

\section{Conclusions}

Under conditions of competition aggravation and reduction of the purchasing power of Ukrainian consumers, the search for effective means of activating the sales activity of a business subject becomes particularly relevant. Marketing acts as an effective means of management that enables managers to identify and satisfy consumers' needs in order to maximize sales. Modern conditions of functioning necessitate the balanced and rational use of the key marketing tools, which are advisable to be grouped according to the spheres of use. Formation and application of effective marketing tools is a prerequisite for ensuring the effectiveness of business as a whole. Prospects for further research lie in the sphere of determination of advantages and disadvantages of each tool, as well as defining features of their use in the system of general business management.

\section{Acknowledgment}

\section{Funding}

The authors received no direct funding for this research.

\section{Citation information}

Orlova, K. (2018). Key marketing tools formation and application in business management. Economics, Management and Sustainability, 3(2), 76-84. doi:10.14254/jems.2018.3-2.6.

\section{References}

Afonina, A. (2015). Strategic Management Tools and Techniques and Organizational Performance: Findings from the Czech Republic. Journal of Competitiveness, 7(3), 19-36. https://doi.org/10.7441/joc.2015.03.02.

Bachmann, F., \& Vaculík, J. (2008). Instruments for the marketing of services and their implementation. Retrieved from http://pernerscontacts.upce.cz/08_2008/Bachmann.pdf.

Bendle, N. T., \& Wang, X. (S.) (2017). Marketing accounts. International Journal of Research in Marketing, 34 (3), 604-621. https://doi.org/10.1016/j.ijresmar.2017.03.002.

Burnett, J. (2008). Core Concepts of Marketing. Retrieved from http://www.freeinfosociety.com/media/pdf/2936.pdf.

Cegliński, P. (2016). Use of strategic marketing management tools in contemporary enterprises. Marketing i Zarzq̨dzanie, 5 (46), 9-16. https://doi.org/10.18276/miz.2016.46-01.

De Vries, L., Gensler, S., \& Leeflang, P. S. H. (2017) Effects of Traditional Advertising and Social Messages on Brand-Building Metrics and Customer Acquisition. Journal of Marketing, 81 (5), 1-15. http://dx.doi.org/10.1509/jm.15.0178.

Fuchedji, V. (2013). SWOT-analysis as a tool of anti-crisis financial management. Actual problems of development of region's economy, 9 (2), 156-161. Retrieved from http://dspace.oneu.edu.ua. [In Ukrainian].

Goi, C. L. (2005). Marketing Mix: A Review of 'P'. Journal of Internet Banking and Commerce, 10 (2). Retrieved from http://www.icommercecentral.com/open-access/marketing-mix-a-reviewof.php?aid=38598.

Kjeldgaard, D., Askegaard, S., Rasmussen, J. Ø., \& Østergaard, P. (2017). Consumers' collective action in market system dynamics: A case of beer. Marketing Theory, 17(I), 51-70. https://doi.org/10.1177/1470593116658197.

Kotler, P., \& Keller, K. L. (2012). Marketing Management. (14th ed.). New Jersey: Prentice Hall. 
Lehkyi, O., \& Sokhatska, O. (2016). Development of marketing communications tools of breweries in the digital economy. Intellect-XXI, 5, 84-90. [In Ukrainian].

Maslak, O., \& Romanenko, S. (2010). Application of marketing tools in e-commerce. Herald of Kremenchuk Mykhailo Ostrohradskyi State University, 1(1), 183-186. [In Ukrainian].

Milichovský, F. (2013). New tools for effective marketing communications. Acta Univ. Bohem. Merid., 16(1), 35-43. Retrieved from: https://www.researchgate.net/publication /279058115_New_Tools_for_Effective_Marketing_Communications.

Patel, D. (2017). 10 Tools Helping Companies Manage Big Marketing Data. Retrieved from https://www.entrepreneur.com/article/298046.

Porter, M. (1998). Competitive strategy. Techniques for analyzing industries and competitors. New York: The Free Press.

Quality management. (n.d.). Retrieved from http://www.kpms.ru/General_info/Benchmarking.htm. [In Russian].

Rigby, D., \& Bilodeau, B. (2015). Management tools \& trends 2015. Retrieved from http://www.bain.com/publications/articles/management-tools-and-trends-2015.aspx.

Rossokha, V. (2012). Industrial and consumer marketing: features and tools. AgroInKom, 7-9, 85-89. [In Ukrainian].

Šonková, T., \& Grabowska, M. (2015). Customer engagement: Transactional vs. relationship marketing. Journal of International Studies, 8(1), 196-207.

State Statistics Service of Ukraine. (n.d.). Retrieved from http://www.ukrstat.gov.ua/ [In Ukrainian].

WebFinance Inc. (n.d.). Business Dictionary. Retrieved from http://www.businessdictionary.com/definition/marketing-tools.html.

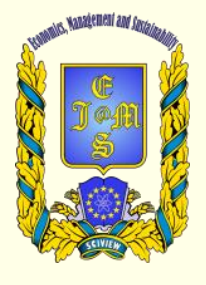

() 2016-2018, Economics, Management and Sustainability. All rights reserved.

This open access article is distributed under a Creative Commons Attribution (CC-BY) 4.0 license.

You are free to:

Share - copy and redistribute the material in any medium or format Adapt - remix, transform, and build upon the material for any

purpose, even commercially.

The licensor cannot revoke these freedoms as long as you follow the license terms.

Under the following terms:

Attribution - You must give appropriate credit, provide a link to the license, and indicate if changes were made.

You may do so in any reasonable manner, but not in any way that suggests the licensor endorses you or your use.

No additional restrictions

You may not apply legal terms or technological measures that legally restrict others from doing anything the license permits.

Economics, Management and Sustainability (ISSN: 2520-6303) is published by Scientific Publishing House "CSR",

Poland, EU and Scientific Publishing House "SciView", Poland

Publishing with JEMS ensures:

- Immediate, universal access to your article on publication

- High visibility and discoverability via the JEMS website

- Rapid publication

- Guaranteed legacy preservation of your article

- Discounts and waivers for authors in developing regions

Submit your manuscript to a JEMS at http://jems.sciview.net or submit.jems@sciview.net

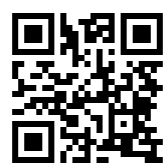

